\title{
Analisis Faktor-Faktor yang Memengaruhi Non Performing Financing di PT TAF dan Pengendaliannya
}

\author{
Analysis of Factors Affecting Non Performing Financing in PT TAF and Its Control
}

\author{
Tri Wahyudi ${ }^{1 *}$, Harianto ${ }^{1}$, Sahara $^{1}$ \\ ${ }^{1)}$ Sekolah Bisnis, Institut Pertanian Bogor, Jl. Raya Pajajaran, Bogor 16151
}

\begin{abstract}
PT TAF is one of multifinance companies in Indonesia. The increase in low segment sales from 2013-2017 with a high credit amount led to an increase in the quality of PT TAF's receivables categorized as Non Performing Financing $(N P F)$. This increase in NPF was also accompanied by an increase in PT TAF's net loss in 2017 and affected the company's profits. Therefore an analysis is needed to find out factors that influence the amount of credit and NPF, in order to formulate the strategy to manage it. This study uses secondary data of PT TAF debtors which related to the amount of credit, debtor delays and NPF from 2013 to 2017. The approach of this study is a case study in PT TAF about the level of NPF from 2013 -2017. The method used in this study is descriptive analysis and statistical tests. Multiple linear regression is performed to determine the factors that influence the amount of credit, while binary logistic regression is carried out to determine the factors that influence NPF. The results of the analysis will be used to formulate a strategy proposal for controlling NPF at PT TAF. Factors that significantly influence the amount of the credit are vehicle price, age, loan interest, installment amount, income, down payment, type of first installment, type of vehicle, education, gender, credit package, and credit tenor. The factors that influence NPF are the amount of credit, Loan to Value (LTV), the residence area of the debtor and inflation. The proposed strategy formulations are: to consider factors which affecting amount of credit in granting credit, to increase the debtor portfolio with LTV less than or equal to 80 percent, avoid low down payment and long tenor products, strengthen collection organizational structures and increase team collection capabilities, and utilize the Financial Information Service System from OJK to obtain information about the debtors.
\end{abstract}

Keywords: amount of credit, loan to value, multifinance, non performing financing.

\begin{abstract}
ABSTRAK
PT TAF adalah salah satu perusahaan pembiayaan yang ada di Indonesia. Peningkatan penjualan low segment dari tahun 2013-2017 dengan besaran kredit tinggi menyebabkan kualitas piutang di PT TAF yang dikategorikan sebagai Non Performing Financing (NPF) mengalami peningkatan. Peningkatan NPF ini juga diiringi dengan peningkatan rugi bersih/net loss PT TAF pada tahun 2017 dan mempengaruhi keuntungan perusahaan. Oleh karena itu dibutuhkan analisis untuk mengetahui faktor-faktor yang memengaruhi besaran kredit dan NPF, sehingga bisa dirumuskan strategi penanganannya. Penelitian ini menggunakan data sekunder berupa debitur PT TAF yang berkaitan dengan besaran kredit (total pinjaman), keterlambatan debitur dan (NPF) dari tahun 2013 sampai dengan tahun 2017. Pendekatan penelitian ini adalah studi kasus di PT TAF tentang tingkat Non Performing Financing dari tahun 20132017. Metode yang digunakan dalam penelitian ini adalah analisis deskriptif dan uji statistik. Regresi linear berganda dilakukan untuk mengetahui faktor-faktor yang memengaruhi besaran kredit, sedangkan regresi logistik biner dilakukan untuk mengetahui faktor-faktor yang memengaruhi NPF. Hasil analisis akan digunakan untuk merumuskan usulan strategi dalam mengendalikan NPF di PT TAF. Faktor-faktor yang berpengaruh nyata terhadap besaran kredit adalah harga kendaraan, umur, bunga kredit, jumlah angsuran, penghasilan, uang muka, tipe angsuran pertama, tipe kendaraan, pendidikan, gender, paket kredit, dan tenor kredit. Sedangkan faktor-faktor yang mempengaruhi NPF adalah besaran kredit, Loan to Value (LTV), area debitur dan inflasi. Rumusan strategi yang diusulkan adalah: mempertimbangkan faktor yang mempengaruhi besaran dalam pemberian kredit, memperbanyak portofolio debitur dengan LTV kurang atau sama dengan 80 persen, menghindari produk pembiayaan uang muka rendah dan tenor panjang, penguatan struktur organisasi collection dan peningkatan kemampuan team collection, dan memanfaatkan Sistem Layanan Informasi Keuangan (SLIK) dari OJK untuk memperoleh informasi debitur.
\end{abstract}

Kata Kunci: besaran kredit, loan to value, multifinance, non performing financing.

*Corresponding author

Alamat e-mail: 3triwoel@gmail.com 


\section{PENDAHULUAN}

Kisah sukses industri otomotif bermula dari perubahan pola pengeluaran domestik yang kuat. Pengeluaran beralih dari konsumsi pokok ke konsumsi yang bersifat bebas menentukan sendiri kebutuhannya di tengah meningkatnya tingkat pendapatan. Kepemilikan mobil adalah simbol dari kemajuan ekonomi dan memiliki posisi sangat tinggi pada daftar produk keinginan konsumen. Pembelian mobil memerlukan pertumbuhan ekonomi yang lebih kuat dan ketersediaan keuangan di tingkat bunga yang relatif rendah (Abhyankar, 2012).

Penjualan mobil di Indonesia cukup tinggi, selalu berkisar di atas 1 juta unit dari tahun 2013-2017, menunjukkan bahwa terjadi perubahan kebebasan menentukan pemenuhan kebutuhan berdasarkan peningkatan penghasilan. Kredit menjadi salah satu alternatif untuk mengatasi perbedaan pendapatan dan pengeluaran untuk pembelian mobil atau aset rumah tangga lainnya. Kebutuhan akan kredit mobil di Indonesia dipenuhi oleh produk pembiayaan yang ditawarkan oleh perusahaan pembiayaan atau multifinance.

Pertumbuhan perusahaan pembiayaan dari tahun 2013 sampai dengan 2017 secara jumlah mengalami penurunan dari 202 di tahun 2013 menjadi 193 di tahun 2017. Penurunan jumlah perusahaan pembiayaan ini dikarenakan adanya pencabutan izin usaha oleh Otoritas Jasa Keuangan. Pertumbuhan perusahaan pembiayaan ini terlihat pada Gambar 1 berikut.

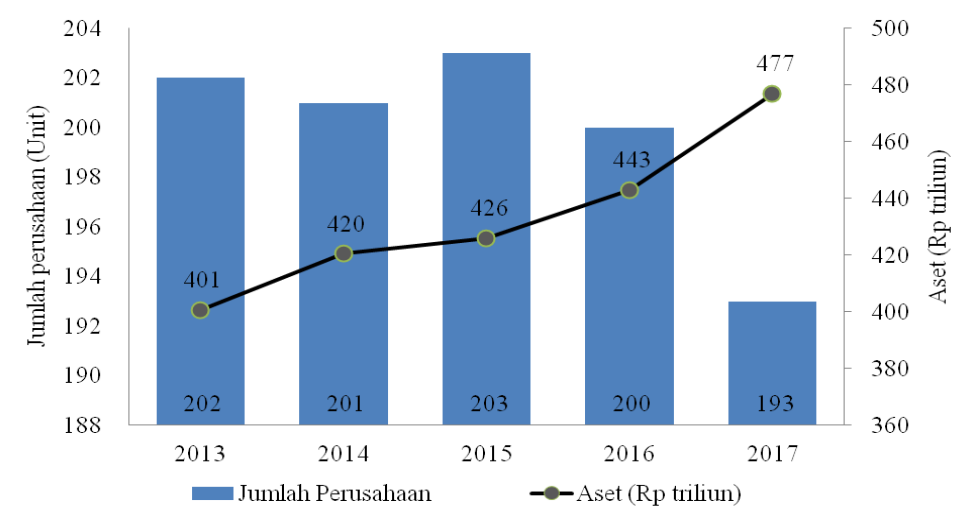

Gambar 1. Jumlah (unit) dan aset perusahaan pembiayaan di Indonesia tahun 2013-2017 (Rp triliun) Sumber: OJK (2018)

Bertambahnya aset perusahaan pembiayaan ini menggambarkan bisnis pembiayaan masih sangat menarik dan pasarnya terus tumbuh. Pertumbuhan aset perusahaan pembiayaan tersebut juga mendorong peningkatan penjualan kendaraan bermotor, terutama mobil. Menurut data Gabungan Industri Kendaraan Bermotor Indonesia atau Gaikindo, penjualan mobil berfluktuasi sepanjang tahun 2013-2017 dengan pemimpin pasar masih dipegang oleh merk Toyota, seperti terlihat pada Gambar 2 berikut.

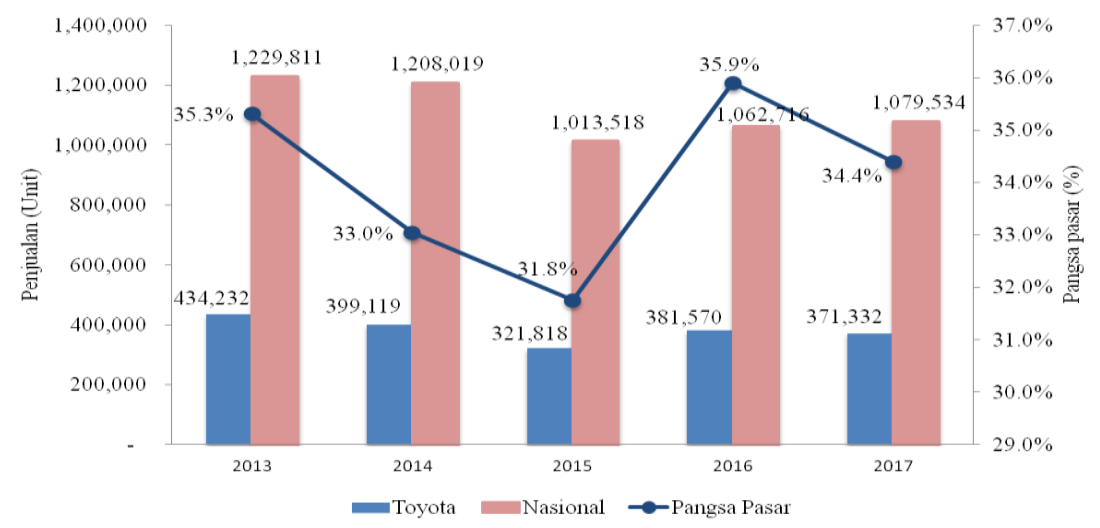

Gambar 2. Jumlah penjualan mobil nasional, Toyota dan pangsa pasar Toyota tahun 2013-2017. Sumber: Gaikindo (2018) 
Penjualan mobil nasional yang terlihat pada Gambar 2, mengalami penurunan 12 persen dari 1.229.811 unit di tahun 2013 menjadi 1.079.534 unit di tahun 2017. Pasar mobil nasional didominasi oleh Toyota yang mampu menguasai pangsa pasar sebesar 34,4 persen atau sekitar 371.332 unit dari total penjualan nasional di tahun 2017. Angka penjualan Toyota ini terkoreksi dari tahun sebelumnya sebesar 381.570 unit dengan pangsa pasar 35,9 persen. Penjualan Toyota tidak berdiri sendiri, melainkan didukung oleh beberapa perusahaan pembiayaan yang salah satunya adalah PT Toyota Astra Finance (PT TAF).

PT TAF didirikan pada tahun 2006, hasil kerja sama antara PT AI, Tbk. dan TFSC. Pendirian PT TAF memang ditujukan untuk mendukung penjualan mobil Toyota di Indonesia. PT TAF mencatatkan pertumbuhan yang sangat cepat terutama pada tahun 2016. Pada tahun tersebut total penyaluran kredit kendaran mobil PT TAF mencapai 81.525 unit dengan nilai 13,48 triliun rupiah, seperti terlihat pada pada Gambar 3 berikut.

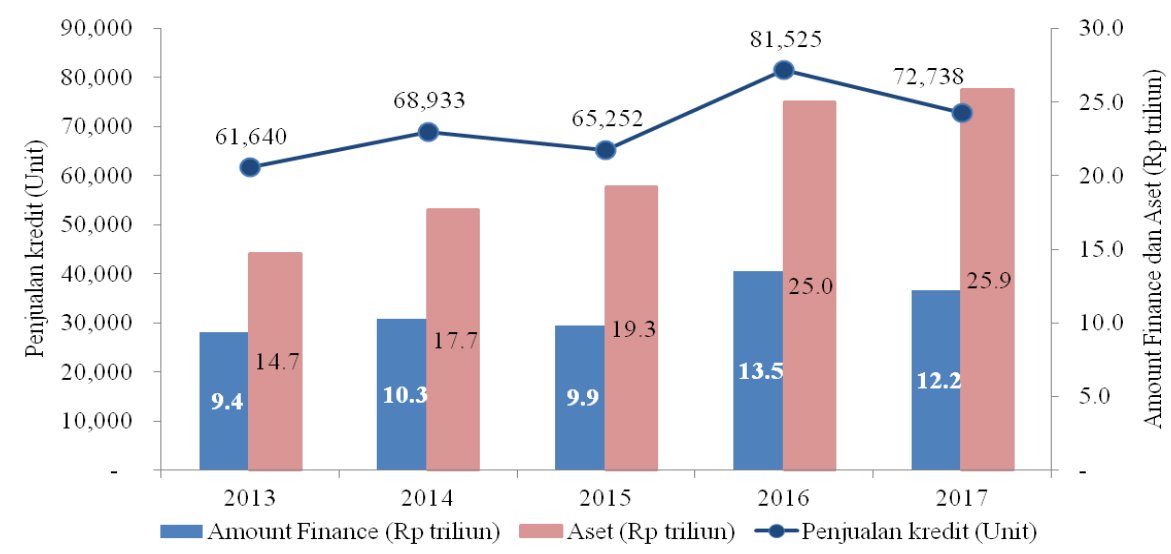

Gambar 3. Pertumbuhan penjualan dan aset PT TAF dari tahun 2013 sampai dengan 2017 (Rp triliun) Sumber: PT TAF (2018)

Peningkatan penjualan Toyota pada tahun 2016 dan 2017 masih mengandalkan kendaraan keluarga yang berkategori low segment atau LCGC (Low Cost Green Car) seperti Agya dan Calya. Peluang ini ditanggapi oleh PT TAF dengan mengeluarkan paket pembiayaan dengan DP rendah dan cicilan ringan yang membutuhkan jangka waktu kredit lebih lama. Skema penjualan kredit dengan DP rendah mengakibatkan jumlah pembiayaan dibandingkan harga kendaraan atau Loan to Value (LTV) meningkat. Penjualan kredit PT TAF dengan LTV $\geq 90$ persen meningkat tajam di tahun 2016 sebanyak 30.227 unit dengan porsi 37 persen dari total penyaluran kredit pada tahun tersebut. Pergerakan penjualan kredit dengan berdasarkan LTV ditampilkan pada Gambar 4.

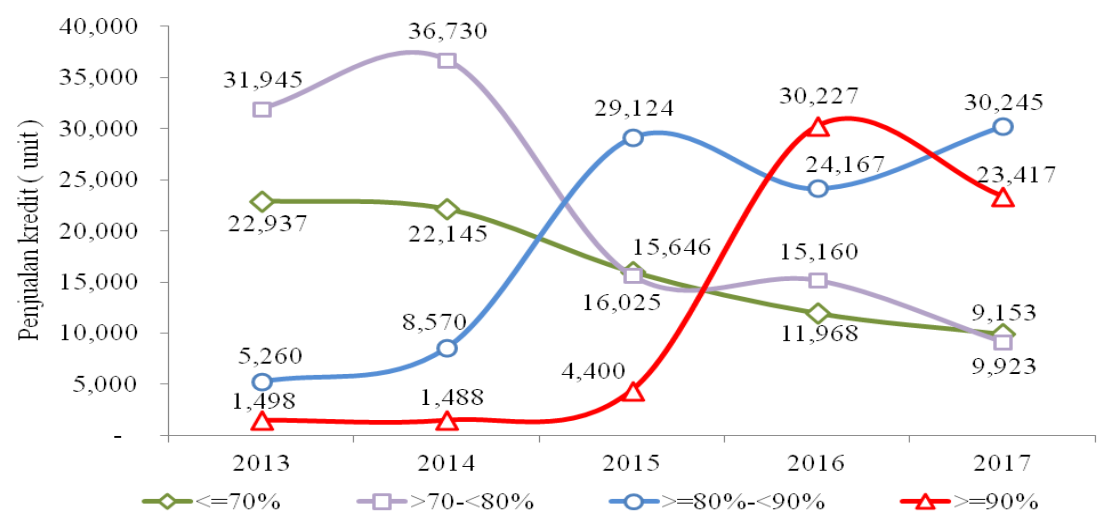

Gambar 4. Jumlah penjualan berdasarkan Loan to Value PT TAF tahun 2013-2017 Sumber: PT TAF (2018)

Jurnal Manajemen dan Organisas

,

Vol. 10 No. 2 , Agustus 2019, 
Seiring peningkatan penjualan dengan LTV tinggi, kualitas piutang di PT TAF yang dikategorikan sebagai NPF (terlambat membayar lebih dari 90 hari) mengalami peningkatan. Peningkatan NPF yang signifikan terlihat di tahun 2017, yang semula 0,32 persen di tahun 2013 menjadi hampir empat kali lipat di tahun 2017 seperti ditampilkan pada Gambar 5. Peningkatan ini menjadi perhatian sekaligus pertanyaan di manajemen apakah peningkatan low segmen dengan LTV $\geq 90$ persen pada tahun 2016 menyebabkan kenaikan NPF di 2017. Walaupun masih di bawah ketentuan OJK yang menyebutkan maksimum NPF adalah 5 persen, tetapi kenaikan yang hampir dua kali lipat perlu diwaspadai.

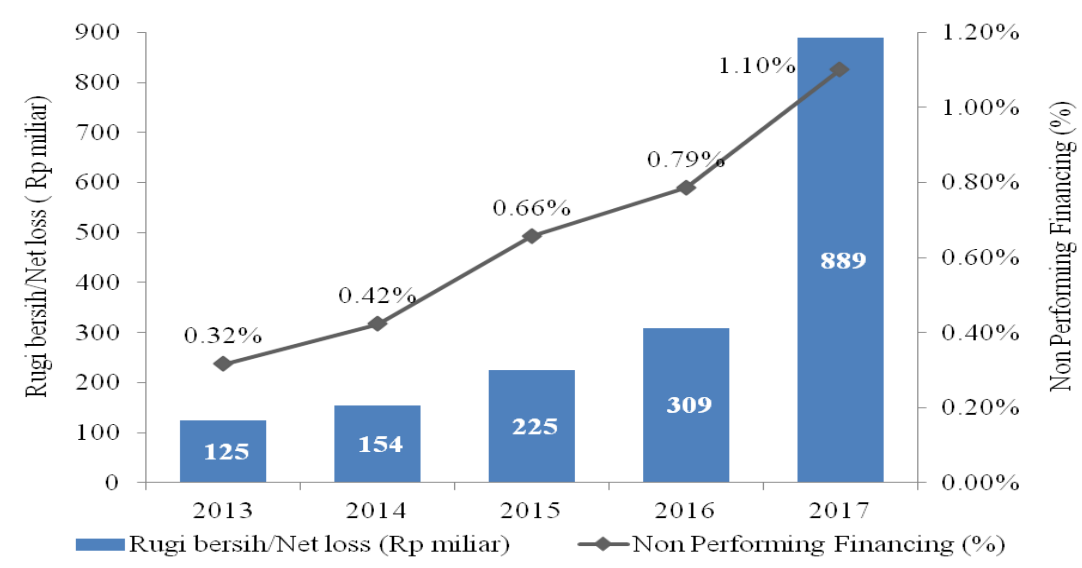

Gambar 5. Peningkatan Non Performing Financing dan rugi bersih / net loss PT TAF tahun 2013-2017 Sumber: PT TAF (2018)

Peningkatan NPF ini juga diiringi dengan peningkatan rugi bersih atau net loss PT TAF, seperti terlihat pada Gambar 5. Peningkatan NPF ini menyebabkan kerugian yang terjadi naik 7,1 kali dari 125 miliar rupiah di tahun 2013 menjadi 889 miliar rupiah di tahun 2017. Kerugian yang terjadi di tahun 2017 menekan profitabilitas PT TAF, sehingga turun dari 350,5 miliar rupiah di tahun 2016 menjadi 17,6 miliar rupiah di tahun 2017, seperti terlihat pada Gambar 6 berikut.

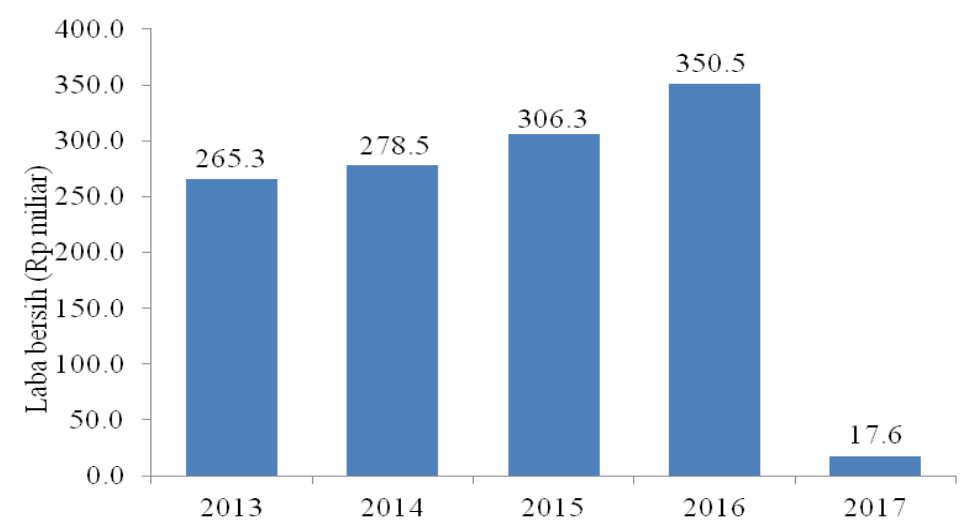

Gambar 6. Pencapaian laba bersih PT TAF tahun 2013-2017 Sumber: PT TAF (2018)

Pembiayaan dengan pembayaran secara angsuran yang dicatatkan sebagai piutang perusahaan pembiayaan selalu ada risiko keterlambatan pembayaran dari debitur. Keterlambatan tersebut menurut Ali (2006) disebut risiko kredit (credit risk), yaitu kerugian yang diderita bank (atau perusahaan pembiayaan), karena debitur tidak melunasi kembali pokok dan bunga pinjamannya secara tepat waktu. Peningkatan penjualan low segment menyebabkan kualitas piutang di PT TAF yang dikategorikan sebagai NPF mengalami peningkatan. Peningkatan NPF ini juga diiringi dengan peningkatan rugi bersih atau net loss PT TAF. Kondisi NPF yang tinggi menurut Musthikaningtyas (2011), akan menyebabkan paling tidak tiga dampak yaitu 
meningkatkan kerugian sehingga menurunkan profitabilitas, menambah biaya operasional, dan menurunkan persentase Capital Adequacy Ratio (CAR).

Sesuai POJK Nomor 29/POJK.05/2014, perusahaan pembiayaan wajib menilai, memantau dan melakukan langkah-langkah yang diperlukan terhadap piutang pembiayaan agar kualitas piutang pembiayaan senantiasa baik. Penilaian kualitas piutang ditetapkan berdasarkan faktor ketepatan pembayaran pokok dan/atau bunga pembiayaan dan dikelompokkan menjadi: lancar (keterlambatan 0-30 hari), dalam perhatian khusus (keterlambatan $>30-90$ hari), kurang lancar (keterlambatan $>90-120$ hari), diragukan (keterlambatan $>120-180$ hari) dan macet (keterlambatan $>180$ hari). Piutang pembiayaan yang dikategorikan sebagai piutang pembiayaan bermasalah (Non Performing Financing) terdiri atas piutang pembiayaan dengan kualitas kurang lancar, diragukan, dan macet (keterlambatan pembayaran lebih dari 90 hari kalender).

Hasil penelitian Setyaningsih et al. (2015), menyatakan faktor-faktor yang mempengaruhi ratio NPL (Non Performing Loan) dapat disebabkan oleh faktor internal seperti kebijakan, SDM, dan lainnya ataupun faktor eksternal melalui perubahan faktor makroekonomi, seperti variabel loans outstanding, BI Rate, dan nilai tukar Rupiah terhadap Dolar. Hasil penelitian ini menunjukkan bahwa Loans outstanding atau besarnya kredit, nilai tukar atau kurs serta dummy pemisahan fungsi RM dan CA memiliki pengaruh terhadap ratio NPL. Perubahan BI Rate yang terjadi selama penelitian tidak berpengaruh terhadap ratio NPL. Ratio NPL terlihat relatif lebih baik dan tidak terpengaruh terhadap kenaikan BI rate. Sedangkan faktor-faktor yang memiliki peluang signifikan terjadinya NPL menurut Suardi (2016), adalah umur, penghasilan, plafon pinjaman, angsuran, tenor, agunan, variabel wilayah dan sektor ekonomi. Hal ini sedikit berbeda dengan hasil penelitian Eliawan (2010) yang menyatakan bahwa hanya karakter debitur, rasio keuntungan dan rasio kecukupan agunan kredit yang berpengaruh signifikan terhadap tingkat pembayaran kewajiban kredit (NPL), sedangkan lainnya tidak berpengaruh signifikan.

Menurut Itoo et al. (2013), yang mengeksplorasi faktor-faktor yang mempengaruhi default pinjaman hipotek, menunjukkan bahwa jenis kelamin peminjam, usia peminjam, status perkawinan peminjam, pendapatan peminjam, suku bunga pinjaman, jenis pinjaman, jumlah pinjaman, jumlah yang dibayar, LTV, LTI, bentuk jaminan agunan, nilai jaminan agunan, tujuan pinjaman dan sekunder keuangan pada keamanan agunan secara signifikan berkorelasi positif dengan jumlah pinjaman yang mengalami kegagalan bayar. Sementara sebagai kualifikasi pendidikan peminjam secara signifikan berkorelasi negatif dengan jumlah pinjaman yang mengalami kegagalan bayar. Adrianda (2011) melakukan penelitian terhadap sepuluh faktor yang dianggap dapat mempengaruhi kolektibilitas debitur. Hasil penelitian dengan menggunakan Ordinal Logistic Regression terdapat tiga faktor yang cukup signifikan mempengaruhi kolektibilitas debitur. Faktor yang berpengaruh tersebut adalah: (1) rasio plafon kredit per total aset, (2) jenis jaminan dan (3) rasio total sales per total asset.

Danny (2008), dalam penelitiannya ini menunjukkan bahwa ketika kemungkinan peminjam gagal bayar pada pinjaman hipotek tidak teramati oleh pemberi pinjaman, dapat menyeleksi peminjam dengan kombinasi rasio Loan to Value (LTV) dan tingkat suku bunga pinjaman. Penelitian ini mengungkapkan bahwa peminjam berisiko tinggi dan rendah, ketika memperoleh credit scoring yang berbeda (dan karena itu membayar tingkat bunga yang berbeda) dapat memperoleh rasio LTV yang lebih tinggi, lebih rendah, atau sama. Oleh karena itu, setiap uji empiris mengenai hubungan antara rasio LTV dan risiko kegagalan bayar harus menggabungkan keterkaitan antara rasio LTV, nilai kredit, dan tingkat suku bunga. Sedangkan Firmansyah (2014) dalam penelitiannya menyatakan bahwa salah satu faktor makroekonomi yaitu inflasi, berpengaruh negatif terhadap pembiayaan bermasalah. Berdasarkan uraian sebelumnya, peningkatan kerugian (net loss) PT TAF terjadi seiring dengan peningkatan LTV dan Non Performing Financing (NPF). Sehingga penelitian ini bertujuan untuk menganalisis faktor-faktor yang memengaruhi besaran kredit (total pinjaman) di PT TAF, menganalisis faktor-faktor yang memengaruhi Non Performing Financing di PT TAF dan merumuskan strategi PT TAF dalam mengendalikan NPF di masa yang akan datang. 


\section{METODE PENELITIAN}

Penelitian ini menggunakan data sekunder berupa data debitur PT TAF yang diambil dari PT TAF. Data yang diambil berkaitan dengan total pinjaman, keterlambatan pembayaran debitur dan Non Performing Financing dari tahun 2013 sampai dengan tahun 2017. Data sekunder lain didapatkan dari literatur dan referensi yang berkaitan dengan NPF. Penelitian ini menggunakan pendekatan studi kasus di PT TAF tentang tingkat Non Performing Financing dari tahun 20132017. Metode yang digunakan dalam penelitian ini adalah analisis deskriptif dan pemodelan statistik yang ditujukan untuk mengetahui faktor-faktor yang memengaruhi pemberian besaran kredit (total pinjaman), dan faktor-faktor penyebab NPF. Faktor-faktor yang digunakan dalam analisis ditentukan berdasarkan penelitian terdahulu. Model dibuat berdasarkan pada penelitianpenelitian sebelumnya. Ada dua model statistik yang digunakan yaitu regresi linear berganda untuk memodelkan besaran kredit, dan regresi logistik biner untuk memodelkan NPF. Menurut Hosmer dan Lemeshow (2000), metode regresi merupakan analisis data yang digunakan untuk mencari hubungan antara variabel dependen/respon (Y) dengan satu atau lebih variabel independen/prediktor $(\mathrm{X})$ dimana variabel respon diasumsikan variabel kontinu. Tujuan dari metode ini adalah memperoleh model yang baik dan sederhana yang menggambarkan variabel dependen dengan sekumpulan variabel independen. Hasil yang didapatkan diharapkan bisa digunakan untuk menyusun usulan langkah-langkah strategis kepada manajemen dalam mengendalikan NPF di PT TAF.

\section{Analisis faktor-faktor yang memengaruhi besaran kredit (total pinjaman) di PT TAF}

Tujuan pertama penelitian ini dijawab dengan analisis mencari keterkaitan pengaruh latar belakang debitur, skema kredit debitur dan pilihan tipe dan peruntukan kendaraan dengan besaran kredit (total pinjaman) yang diberikan perusahaan saat mengambil kredit. Persamaan yang regresi linear berganda digunakan sebagai berikut :

$$
\begin{aligned}
& \mathrm{Y}_{1}=\beta_{0}+\beta_{1} X_{1}+\beta_{2} X_{2}+\beta_{3} X_{3}+\beta_{4} X_{4}+\beta_{5} X_{5}+\beta_{6} X_{6}+\beta_{7} X_{7}+\beta_{8} D_{1}+\beta_{9} D_{2} \\
& +\beta_{10} D_{3}+\beta_{11} D_{4}+\beta_{12} D_{5}+\beta_{13} D_{6}+\beta_{14} D_{7}+\beta_{15} D_{8}+\beta_{16} D_{9}+\beta_{17} D_{10}+ \\
& \beta_{18} D_{11}+\beta_{19} D_{12}+\beta_{20} D_{13}+\beta_{21} D_{14}+\beta_{22} D_{15}+\beta_{23} D_{16}+e_{1}
\end{aligned}
$$

Keterangan :

$\mathrm{Y}_{1}=$ Besaran kredit atau total pinjaman (juta rupiah)

$\mathrm{X}_{1}=$ Harga Kendaraan (juta rupiah)

$\mathrm{X}_{2}=$ Umur Debitur (tahun)

$\mathrm{X}_{3}$ = Bunga Kredit, bunga kredit yang dikenakan ke debitur (persen per annum)

$\mathrm{X}_{4}=$ Jumlah Angsuran, besarnya beban yang harus dibayar debitur tiap bulan, terdiri dari pokok dan bunga pinjaman (juta rupiah)

$\mathrm{X}_{5}=$ Penghasilan/Income ( juta rupiah)

$\mathrm{X}_{6}=$ Uang Muka /Down Payment (juta rupiah)

$\mathrm{X}_{7}=$ Jumlah Pembiayaan/Amount Finance, pokok pinjaman yang diberikan kepada debitur (juta rupiah)

$\mathrm{D}_{1}=$ Dummy variable Tipe Angsuran Pertama/First Installment (ADDM/ADDB)

$\mathrm{D}_{1}=1$ jika angsuran pertama dibayar bersama uang muka atau ADDM (angsuran dibayar dimuka)

$\mathrm{D}_{1}=0$ lainnya

$\mathrm{D}_{2}=$ Dummy variable Tujuan penggunaan kendaraan

$\mathrm{D}_{2}=1$ jika tujuan penggunaan kendaraan untuk private, $\mathrm{D}_{2}=0$ lainnya

$\mathrm{D}_{3}=$ Dummy variable Tipe kendaraan LCGC/Low Cost Green Car

$\mathrm{D}_{3}=1$ jika tipe kendaraan LCGC, $\mathrm{D}_{3}=0$ lainnya

$\mathrm{D}_{4}=$ Dummy variable Tipe kendaraan Minibus

$\mathrm{D}_{4}=1$ jika tipe kendaraan Minibus, $\mathrm{D}_{4}=0$ lainnya

$\mathrm{D}_{5}=$ Dummy variable Tipe kendaraan Truck dan PickUp $\mathrm{D}_{5}=1$ jika Tipe kendaraan Truck dan PickUp, $\mathrm{D}_{5}=0$ lainnya

$\mathrm{D}_{6}=$ Dummy variable Tipe pekerjaan karyawan $\mathrm{D}_{6}=1$ jika Tipe pekerjaan karyawan, $\mathrm{D}_{6}=0$ lainnya 
$\mathrm{D}_{7}=$ Dummy variable Tipe pekerjaan wiraswasta

$\mathrm{D}_{7}=1$ jika tipe pekerjaan wiraswasta, $\mathrm{D}_{7}=0$ lainnya

$\mathrm{D}_{8}=$ Dummy variable Pendidikan

$\mathrm{D}_{8}=1$ jika pendidikan sarjana, $\mathrm{D}_{8}=0$ lainnya

$\mathrm{D}_{9}=$ Dummy variable Tanggungan

$\mathrm{D}_{9}=1$ jika memiliki tanggungan, $\mathrm{D}_{9}=0$ lainnya

$\mathrm{D}_{10}=$ Dummy variable Status pernikahan

$\mathrm{D}_{10}=1$ jika menikah, $\mathrm{D}_{10}=0$ lainnya

$\mathrm{D}_{11}=$ Dummy variable Gender

$\mathrm{D}_{11}=1$ jika laki-laki, $\mathrm{D}_{11}=0$ lainnya

$\mathrm{D}_{12}=$ Dummy variable Paket pembiayaan

$\mathrm{D}_{12}=1$ jika debitur mengambil pembiayaan tipe paket, $\mathrm{D}_{12}=0$ lainnya

$\mathrm{D}_{13}=$ Dummy variable Tenor pembiayaan 24/dua tahun

$\mathrm{D}_{13}=1$ jika debitur mengambil tenor pembiayaan dua tahun, $\mathrm{D}_{13}=0$ lainnya

$\mathrm{D}_{14}=$ Dummy variable Tenor pembiayaan 36/tiga tahun

$\mathrm{D}_{14}=1$ jika debitur mengambil tenor pembiayaan tiga tahun, $\mathrm{D}_{14}=0$ lainnya

$\mathrm{D}_{15}=$ Dummy variable Tenor pembiayaan 48/empat tahun

$\mathrm{D}_{15}=1$ jika debitur mengambil tenor pembiayaan empat tahun, $\mathrm{D}_{15}=0$ lainnya

$\mathrm{D}_{16}=$ Dummy variable Tenor pembiayaan 60/lima tahun

$\mathrm{D}_{16}=1$ jika debitur mengambil tenor pembiayaan lima tahun, $\mathrm{D}_{16}=0$ lainnya

$\beta_{0}=$ Intersep regresi linear berganda

$\beta_{\mathrm{j}}=$ Koefisien regresi variabel independen $\mathrm{j}$, dimana $\mathrm{j}=($ Harga Kendaraan, Umur, Bunga

Kredit, Jumlah Angsuran, Penghasilan/Income, Uang Muka /Down Payment, Jumlah Pembiayaan/Amount Finance, Tipe Angsuran pertama/First Installment (ADDM/ADDB), Tujuan penggunaan kendaraan, Tipe kendaraan LCGC/Low Cost Green Car, Tipe kendaraan minibus, Tipe kendaraan Truck dan PickUp, Tipe pekerjaan Karyawan, Tipe pekerjaan wiraswasta, Pendidikan, Tanggungan, Status pernikahan, Gender, Paket pembiayaan, Tenor pembiayaan 24/dua tahun, Tenor pembiayaan 36/tiga tahun, Tenor pembiayaan 48/empat tahun, dan Tenor pembiayaan 60/lima tahun)

i = Jumlah sampel 22.661 debitur

Model tersebut diharapkan mampu mengetahui faktor-faktor yang memengaruhi besaran kredit dan dapat digunakan membuat prediksi atau dugaan nilai besaran kredit. Selanjutnya hasil ini akan dijadikan salah satu faktor independen dalam tahapan pemenuhan tujuan kedua dan ketiga dalam penelitian dan menjadi faktor dugaan besaran kredit $\left(\hat{Y}_{1}\right)$.

\section{Analisis faktor-faktor yang memengaruhi Non Performing Financing di PT TAF}

Tujuan kedua penelitian ini dijawab dengan analisis faktor-faktor yang memengaruhi Non Performing Financing yang dilakukan dengan menggunakan Binary Logistic Regression. Hal ini dilakukan karena kategori variabel dependen (NPF) yang bersifat biner. Menurut Garson (2014), regresi logistik biner adalah bentuk regresi yang digunakan ketika variabel dependen adalah dikotomus/biner dan variabel independennya jenis apa pun. Pada analisis kedua ini, besaran kredit (total pinjaman) yang pada analisis sebelumnya adalah variabel dependen, pada persamaan ini hasil analisis yang berupa dugaan besaran kredit $\left(\hat{Y}_{1}\right)$ dijadikan variabel independen. Variabel independen lain yang digunakan adalah Loan to Value (LTV), inflasi yang diambil dari laman Bank Indonesia dari tahun 2013-2017, area debitur dan segmen bisnis debitur. Persamaan Binary Logistic Regression yang digunakan sebagai berikut:

$$
Y=c+a_{1} X_{1}+a_{2} X_{2}+\cdots+a_{n} X_{n}
$$

Karena respon dari variabel NPF biner, NPF atau tidak NPF, maka untuk mengetahui faktor yang memengaruhi NPF dan membuat prediksinya dilakukan dengan menggunakan model regresi logistik biner. Transformasi yang digunakan adalah transformasi logit, sehingga persamaan regresi logistik biner menjadi:

$$
\text { Logit NPF }\left(\mathrm{Y}_{2}\right)=\delta_{0}+\delta_{1} \hat{Y}_{1}+\delta_{2} \mathrm{X}_{8}+\delta_{3} \mathrm{X}_{9}+\delta_{4} \mathrm{D}_{17}+\delta_{5} \mathrm{D}_{18}+\delta_{6} \mathrm{D}_{19}
$$

Jurnal Manajemen dan Organisasi 
dimana peluang setiap amatan dapat dihitung dengan menggunakan persamaan:

$$
\mathrm{NPF}\left(\mathrm{Y}_{2}\right)=\frac{1}{1+\mathrm{e}^{-\left(\delta_{0}+\delta_{1} \hat{Y}_{1}+\delta_{2} \mathrm{X}_{8}+\delta_{3} \mathrm{X}_{9}+\delta_{4} \mathrm{D}_{17}+\delta_{5} \mathrm{D}_{18}+\delta_{6} \mathrm{D}_{19}\right)}}
$$

Keterangan:

NPF $\left(\mathrm{Y}_{2}\right)=$ Non Performing Financing $(\mathrm{NPF})$ dengan kategori keterlambatan: NPF $(>90$ hari $)=$ 1 , keterlambatan non NPF $(<=90$ hari $)=0$

$\hat{Y}_{1} \quad=$ Nilai dugaan Besaran kredit (Fits) pada analisis sebelumnya (juta rupiah)

$\mathrm{X}_{8} \quad=$ Loan to Value (Jumlah pembiayaan/Harga kendaraan), perbandingan jumlah pembiayaan dengan harga kendaraan dalam persen (\%)

$\mathrm{X}_{9} \quad=$ Tingkat inflasi , variabel ini menunjukkan tingkat inflasi yang berlaku saat pembiayaan disalurkan kepada debitur dalam persen (\%)

$\mathrm{D}_{17} \quad=$ Dummy variable Lokasi debitur area Jawa

$\mathrm{D}_{17}=1$ jika Lokasi debitur di area Jawa, $\mathrm{D}_{17}=0$ lainnya

$\mathrm{D}_{18} \quad=$ Dummy variable Lokasi debitur area Sumatera

$\mathrm{D}_{18}=1$ jika Lokasi debitur di area Sumatera, $\mathrm{D}_{18}=0$ lainnya

$\mathrm{D}_{19} \quad=$ Dummy variable Bisnis segmen debitur

$\mathrm{D}_{19}=1$ jika bisnis segmennya Jasa $\&$ Perdagangan, $\mathrm{D}_{19}=0$ jika lainnya

$\delta_{0} \quad=$ Intersep regresi logistik

$\delta_{\mathrm{i}} \quad=$ Koefisien regresi variabel independen-i, dimana $\mathrm{i}=$ (besaran kredit, Loan to value

(LTV), area debitur, bisnis segmen, dan tingkat inflasi)

Model yang dihasilkan oleh persamaan tersebut diharapkan mampu digunakan untuk mengetahui faktor-faktor yang memengaruhi NPF. Model persamaan tersebut diharapkan juga dapat digunakan untuk membuat prediksi debitur NPF di PT TAF.

\section{Perumusan strategi PT TAF dalam mengendalikan NPF di masa yang akan datang}

Berdasarkan model persamaan yang sudah terbentuk, maka untuk menjawab tujuan ketiga, akan disusun langkah-langkah strategi dalam pengendalian NPF berdasarkan kedua model diatas. Usulan ini diharapkan akan membantu PT TAF dalam mengendalikan NPF di masa mendatang.

Tahapan ringkas penelitian ini ditampilkan pada Tabel 1 di bawah ini. Berdasarkan Tabel 1 tersebut, tujuan penelitian dijawab dengan langkah langkah penelitian yang akan dilakukan.

Tabel 1. Tahapan penelitian

\begin{tabular}{|c|c|c|c|}
\hline Tujuan & Kerangka & Alat Analisis & Hasil \\
\hline Mempersiapkan data & $\begin{array}{l}\text { Pengambilan data dari } \\
\text { database } \\
\text { Cleaning data }\end{array}$ & $\begin{array}{l}\text { Microsoft Excel, } \\
\text { SPSS, R-Studio }\end{array}$ & $\begin{array}{l}\text { Data yang siap } \\
\text { dianalisis }\end{array}$ \\
\hline $\begin{array}{l}\text { 1. Menguji faktor-faktor yang } \\
\text { mempengaruhi besaran kredit. } \\
\text { 2. Membuat persamaan regresi linear } \\
\text { berganda } \\
\text { 3. Membuat prediksi besaran kredit }\end{array}$ & $\begin{array}{l}\text { Regresi linear } \\
\text { berganda }\end{array}$ & $\begin{array}{l}\text { SPSS dan } \\
\text { Microsoft Excel }\end{array}$ & $\begin{array}{l}\text { 1. Faktor-faktor yang } \\
\text { memengaruhi } \\
\text { besaran kredit } \\
\text { 2. Persamaan regresi } \\
\text { linear berganda } \\
\text { 3. Prediksi besaran } \\
\text { kredit }\end{array}$ \\
\hline $\begin{array}{l}\text { 1. Menguji faktor-faktor yang } \\
\text { mempengaruhi NPF } \\
\text { 2. Membuat persamaan untuk } \\
\text { pengklasifikasian NPF }\end{array}$ & $\begin{array}{l}\text { Menggunakan Binary } \\
\text { Logistic Regression } \\
\text { untuk membangun } \\
\text { model }\end{array}$ & $\begin{array}{l}\text { SPSS dan } \\
\text { Microsoft Excel }\end{array}$ & $\begin{array}{l}\text { 1. Faktor-faktor yang } \\
\text { mempengaruhi NPF } \\
\text { 2. Persamaan regresi } \\
\text { logistik biner }\end{array}$ \\
\hline $\begin{array}{l}\text { Merumuskan langkah-langkah } \\
\text { strategi untuk mengendalikan NPF }\end{array}$ & $\begin{array}{l}\text { Merumuskan strategi } \\
\text { pengen-dalian NPF }\end{array}$ & $\begin{array}{l}\text { Analisis } \\
\text { kualitatif }\end{array}$ & $\begin{array}{l}\text { Usulan langkah- } \\
\text { langkah pengen-dalian } \\
\text { NPF }\end{array}$ \\
\hline
\end{tabular}

Kerangka pemikiran penelitian ini dimulai dengan analisis terhadap faktor-faktor besaran kredit untuk mengetahui pilihan debitur akan produk kredit, sehingga memudahkan analisis selanjutnya. Faktor-faktor yang dianalisis dikelompokkan menjadi dua, yaitu faktor-faktor untuk besaran kredit (total pinjaman) dan faktor-faktor yang mempengaruhi NPF debitur. Faktor besaran kredit (total pinjaman) sendiri dikelompokkan menjadi dua: 
1. Credit Term yang terdiri dari faktor harga kendaraan, bunga kredit, jumlah angsuran, uang muka (Down Payment), jumlah pembiayaan (Amount Finance), tipe angsuran pertama (ADDM/ADDB), tipe kendaraan, paket kredit dan tenor kredit.

2. Internal Debitur yang terdiri dari umur, penghasilan, tujuan penggunaan, tipe pekerjaan, tingkat pendidikan, tanggungan, status pernikahan, dan gender.

Sedangkan untuk analisis faktor penyebab NPF faktor-faktor yang akan dianalisis adalah besaran kredit (total pinjaman), Loan to Value (LTV), area cabang atau debitur, bisnis segmen dan inflasi. Besaran kredit yang pada analisis sebelumnya sebagai variable dependen pada analisis NPF dijadikan salah satu variable independen. Setelah didapatkan variabel yang berpengaruh dan model yang diharapkan, akan dilakukan penyusunan usulan langkah langkah manajerial dalam penjualan kredit di PT TAF. Kerangka pemikiran penelitian ini dapat dilihat pada Gambar 4.

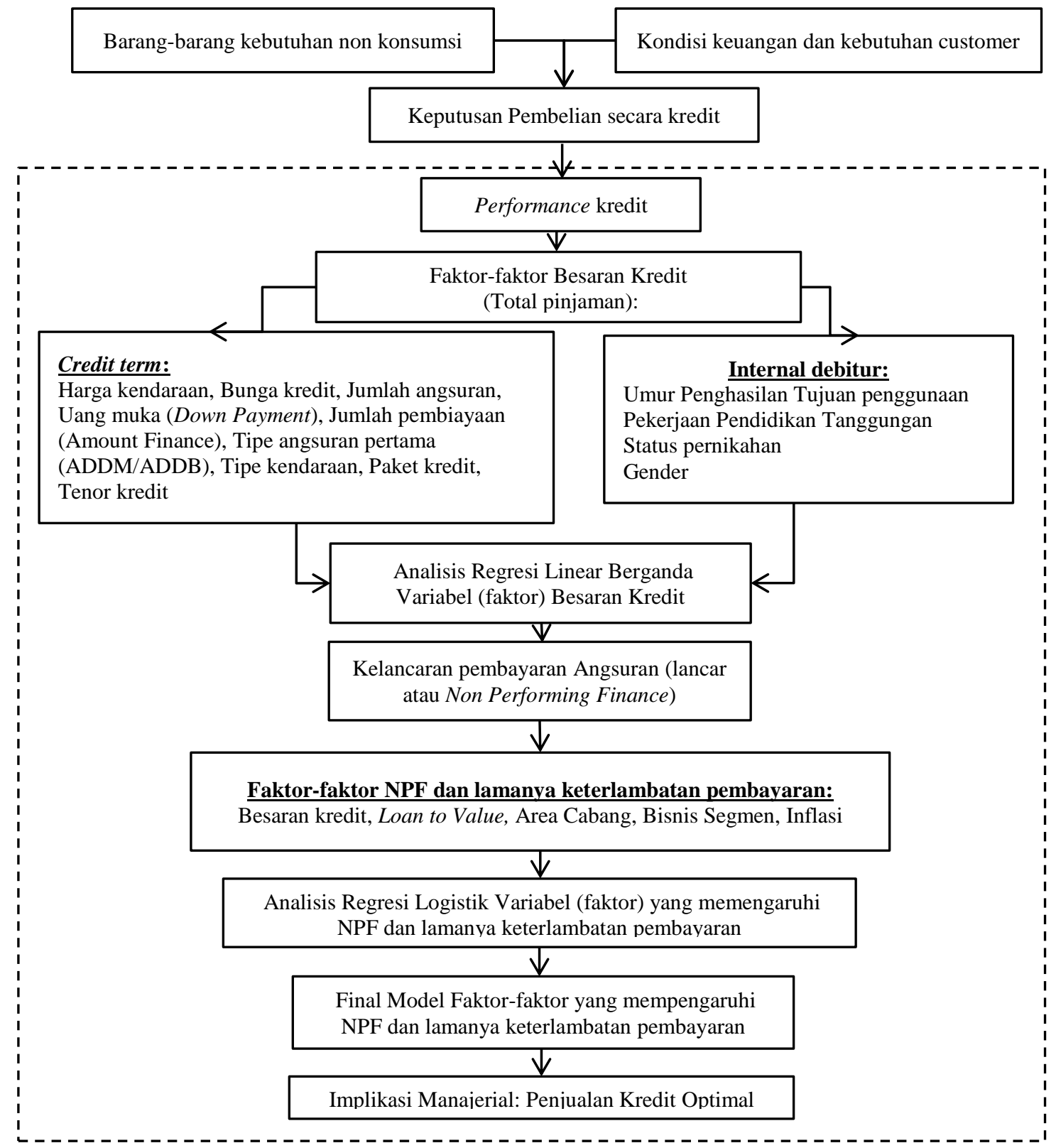

Gambar 7. Kerangka Pemikiran 


\section{HASIL DAN PEMBAHASAN}

\section{Gambaran Umum Perusahaan}

PT Toyota Astra Financial Services (PT TAF) adalah salah satu perusahaan pembiayaan di Indonesia yang didirikan pada tahun 2006. PT TAF dimiliki oleh PT Astra International, Tbk (AI) dan Toyota Financial Services Corporation (TFSC) dengan kepemilikan saham masing-masing 50 persen. PT TAF mengutamakan pembiayaan kendaraan baru merek Toyota dan atau merek lainnya yang diproduksi oleh Toyota Motor Corporation dan/atau afiliasinya. Hal ini dilakukan untuk memperkuat value chain yang sudah terjalin cukup lama di antara pemegang saham PT TAF. PT TAF menjadi sales finance company ke-31 dari TFSC yang beroperasi secara global di lebih dari 30 negara. Jaringan TFSC ini dikembangkan untuk mendukung penjualan produk Toyota dan afiliasinya seperti Daihatsu dan Lexus, melalui pembiayaan konsumen dan sewa pembiayaan (leasing). PT TAF beroperasi sejak Mei 2006 dimulai dari daerah DKI Jakarta, Jawa, dan Bali. Sampai dengan akhir tahun 2017 PT TAF sudah memiliki 35 Kantor Cabang di seluruh Indonesia dan 1 Kantor Perwakilan, dengan jumlah karyawan PT TAF sudah mencapai 1.172 orang dengan latar belakang pendidikan beragam.

\section{Deskripsi Data Penelitian}

Penelitian ini dimulai dengan tahap persiapan data, dimana pada awalnya diambil data debitur PT TAF yang aktif dari tahun 2013 sampai dengan 2017 sebanyak 438.254 debitur. Data tersebut dipisahkan dan hanya diambil debitur retail bukan fleet atau korporasi agar lebih homogen sebanyak 297.385 debitur. Data yang diambil merupakan data gabungan dari skema kredit, tipe dan spesifikasi kendaraan, profil debitur, dan history pembayaran. Proses selanjutnya dari data debitur retail sebanyak 297.385 debitur dibersihkan dari data outlier seperti umur debitur dan penghasilan tidak sesuai isinya. Hasil cleaning data ini didapatkan data untuk diolah dalam penelitian ini sebanyak 22.661 debitur.

\section{Analisis Faktor-faktor yang Memengaruhi Besaran Kredit (total pinjaman) di PT TAF}

Analisis dilakukan dengan menggunakan regresi linear berganda. Hasil analisis awal dengan menggunakan semua variabel masih terdapat multikolinearitas yang cukup besar (nilai Variance Inflating Factor/VIF >10) antara variabel harga kendaraan, uang muka, dan jumlah pembiayaan (Amount Finance). Hal ini terjadi karena jumlah pembiayaan (Amount Finance) merupakan fungsi dari harga kendaraan dikurangi dengan uang muka, ditambahkan dengan asuransi kendaraan yang dikredit. Multikolinearitas yang terjadi diatasi dengan menghilangkan variabel Jumlah pembiayaan (Amount Finance) pada regresi linear berganda selanjutnya. Hasil regresi linear berganda ini menjadi lebih baik, dimana sudah tidak terjadi multikolinearitas antar variabel bebas. Kerasionalan model yang terbentuk juga bisa dilihat dari koefisien regresi, terutama pada tanda (positif atau negatif) yang merepresentasikan pengaruh dari variabel bebas, seperti terlampir pada Tabel 2.

Berdasarkan Tabel 2 di bawah, ditemukan variabel-variabel yang tidak berpengaruh nyata terhadap besaran kredit (total pinjaman) pada taraf nyata lima persen dengan nilai $p$-value $>0,050$. Variabel-variabel yang tidak berpengaruh nyata terhadap besaran kredit pada persamaan ini adalah tujuan kendaraan-private $(p$-value $=0,888)$, tipe pekerjaan-karyawan $(p$-value $=602)$, tipe pekerjaan-wiraswasta $(p$-value $=0,221)$, tanggungan $(p$-value $=0,114)$, dan status pernikahan $(p$ value $=0,469)$. Hasil dugaan besaran kredit akan digunakan sebagai variabel untuk menganalisa Non Performing Financing, sehingga faktor yang tidak berpengaruh terhadap besaran kredit, cenderung akan tidak berpengaruh juga terhadap NPF. Hal ini berbeda dengan beberapa penelitian terdahulu, menurut Sekyi (2017), status pernikahan merupakan salah satu variabel yang berpengaruh signifikan terhadap jumlah pinjaman atau besaran kredit. Itoo et al. (2013) dalam penelitiannya menyebutkan bahwa tujuan pinjaman dan status pernikahan berpengaruh positif terhadap kegagalan pembayaran. 
Tabel 2. Hasil regresi linear berganda besaran kredit (total pinjaman)

\begin{tabular}{lccc}
\hline \multirow{2}{*}{ Model } & \multicolumn{2}{c}{ Unstandardized Coeff. } & \multirow{2}{*}{ p-value } \\
\cline { 2 - 3 } & \multicolumn{1}{c}{$\mathrm{B}$} & Std. Error & 0,000 \\
(Constant) & $-70,321$ & 0,984 & 0,000 \\
Harga Kendaraan & 1,301 & 0,002 & 0,005 \\
Umur & 0,027 & 0,010 & 0,000 \\
Bunga Kredit & 4,105 & 0,039 & 0,009 \\
Jumlah Angsuran & 0,012 & 0,004 & 0,037 \\
Penghasilan & $-0,002$ & 0,001 & 0,000 \\
Uang Muka & $-1,235$ & 0,004 & 0,000 \\
Tipe Angsuran Pertama & $-4,851$ & 0,234 & 0,888 \\
Tujuan-Private & $-0,048$ & 0,339 & 0,000 \\
Tipe Kendaraan LCGC & $-6,517$ & 0,318 & 0,000 \\
Tipe Kendaraan Minibus & 1,364 & 0,244 & 0,000 \\
Tipe Kendaraan Truck\&PU & $-9,369$ & 0,495 \\
Tipe Pekerjaan Karyawan & $-0,198$ & 0,379 & 0,221 \\
Tipe Pekerjaan Wiraswasta & 0,459 & 0,375 & 0,006 \\
Pendidikan-Sarjana & 0,525 & 0,191 & 0,114 \\
Tanggungan-Memiliki & 0,294 & 0,186 & 0,469 \\
Status Pernikahan-Menikah & $-0,128$ & 0,176 & 0,002 \\
Gender- Laki-laki & $-0,641$ & 0,000 \\
Paket-Ya & 5,997 & 0,204 & 0,000 \\
Tenor-24 & 8,477 & 0,000 \\
Tenor-36 & 23,342 & 0,000 \\
Tenor-48 & 37,259 & 0,545 & 0,000 \\
Tenor-60 & 58,357 & 0,495 & 0,524 \\
\hline
\end{tabular}

Faktor-faktor yang berpengaruh terhadap besaran kredit, cenderung akan berpengaruh juga terhadap NPF, hal ini karena hasil dugaan besaran kredit akan dijadikan variabel independen untuk menganalisa Non Performing Financing. Berdasarkan Tabel 2, variabel harga kendaraan memiliki pengaruh nyata terhadap besaran kredit dengan nilai $p$-value 0,000 . Nilai koefisien harga kendaraan adalah 1,301 yang dapat diterjemahkan, saat harga kendaraan naik sebesar satu juta rupiah, maka besaran kredit yang diberikan kepada debitur akan naik kurang lebih 1,301 juta rupiah, dengan asumsi nilai variabel lain tetap. Harga kendaraan yang dijadikan agunan berpengaruh terhadap besaran kredit, hal ini selaras dengan penelitian Itoo et al. (2013) dan Lusian (2015), yang menyatakan nominal atau nilai agunan berpengaruh terhadap NPL.

Umur debitur pada persamaan regresi ini berpengaruh nyata terhadap besaran kredit dengan nilai $p$-value 0,002 . Peningkatan umur debitur satu tahun akan mempengaruhi peningkatan besaran kredit sebesar 0,027 juta rupiah. Walaupun peningkatan besaran kredit secara rupiah tidak terlalu besar, namun kecenderungan jika umur debitur naik, maka pemberian total pinjaman dari perusahaan ke debitur juga meningkat. Hal ini dimungkinkan karena secara umur, tingkat kemampuan ekonomi debitur cenderung akan lebih baik pada umur yang kian matang. Hasil penelitian ini sesuai dengan penelitian yang dilakukan oleh Chen dan Chivakul (2008) serta Suardi (2016). Sedangkan menurut Budiana (2017) menyatakan rata-rata usia debitur berpengaruh negative terhadap NPL.

Bunga kredit yang dikenakan kepada debitur saat mengambil kredit berpengaruh nyata terhadap besaran kredit dengan nilai p-value 0,000. Setiap kenaikan bunga kredit satu persen (\%), maka besaran kredit yang disalurkan kepada debitur akan naik 4,105 juta rupiah, sesuai koefisien persamaannya. Hal ini dikarenakan besaran kredit didapatkan dari bunga kredit dikalikan dengan jumlah pembiayaan (pokok hutang) ditambah dengan jumlah pembiayaan tersebut. Semakin besar bunga kredit yang dikenakan, maka akan menambah besaran kredit debitur. Penelitian terdahulu yang dilakukan Musthikaningtyas (2011), Yohana (2011), Itoo et al. (2013), Messai dan Jouini (2013), Abadi (2014), Dewi dan Suryanawa (2015), dan Murthy et al. (2017), memiliki hasil yang sesuai dengan penelitian ini.

Jumlah angsuran perbulan dari debitur berdasarkan hasil regresi menunjukkan pengaruh yang nyata terhadap besaran kredit dengan nilai $p$-value 0,009 . Setiap kenaikan jumlah angsuran satu juta rupiah akan mempengaruhi kenaikan besaran kredit sebesar 0,012 juta rupiah. Hal ini bisa dijelaskan karena besaran kredit merupakan fungsi dari jumlah angsuran dikalikan dengan

Jurnal Manajemen
dan Organisasi
(JMO),
Vol. 10 No. 2,
Agustus 2019,
Hal. 72-91


tenor yang diambil debitur. Semakin besar jumlah angsuran, akan semakin besar nilai besaran kreditnya, dengan asumsi tenor yang diambil debitur sama. Hasil ini sesuai dengan penelitian Musthikaningtyas (2011), Itoo et al. (2013), dan Suardi (2016), yang menyatakan bahwa jumlah angsuran berpengaruh terhadap NPL.

Penghasilan atau income debitur, berpengaruh nyata terhadap besaran kredit dengan nilai p-value 0,037. Tanda negatif (-) pada koefisien penghasilan menunjukkan setiap kenaikan penghasilan debitur satu satuan (juta rupiah) akan menurunkan nilai besaran kredit 0,002 juta rupiah. Penurunan nilai besaran kredit akibat kenaikan income debitur dapat disebabkan semakin besar penghasilan debitur, maka debitur cenderung mengambil kredit dengan uang muka yang lebih besar dibandingkan dengan debitur yang berpenghasilan lebih rendah. Selain itu bunga kredit yang dikenakan pada debitur dengan uang muka besar akan lebih rendah dibandingkan dengan debitur dengan uang muka rendah, dengan kondisi kendaraan dan tenor kredit kedua debitur tersebut yang diambil sama. Hal ini sesuai dengan penelitian Chen dan Chivakul (2008) yang menyatakan bahwa penghasilan berpengaruh positif terhadap pemberian pinjaman. Hasil ini diperkuat dengan penelitian Yusuf W. et al. (2009), Musthikaningtyas (2011), Yudha (2011), Itoo et al. (2013) dan Suardi (2016), yang menyatakan penghasilan berpengaruh terhadap status kredit dan NPL.

Besaran kredit dipengaruhi nyata oleh variabel uang muka yang dibayarkan debitur dengan nilai $p$-value 0,000 . Koefisien uang muka pada persamaan regresi linear ini bertanda negatif sebesar -1,235. Koefisien ini dapat diartikan bahwa setiap kenaikan uang muka (down payment) satu juta rupiah, akan menurunkan besaran kredit sebesar 1,235 juta rupiah. Penjelasan lebih lanjut karena besaran kredit didapatkan dari harga kendaraan dikurangi uang muka dan ditambahkan perkalian bunga kredit sesuai tenor yang dikenakan kepada debitur terhadap nilai harga kendaraan dikurangi uang muka tersebut. Sehingga semakin besar uang muka, maka besaran kredit akan semakin turun sesuai koefisien persamaan. Pengaruh besarnya uang muka yang diteliti oleh Yudha (2011) menyatakan bahwa persentase uang muka berpengaruh nyata terhadap terjadinya kredit macet KPR.

Tipe angsuran pertama adalah variabel dummy dalam persamaan regresi ini. Variabel ini berpengaruh nyata terhadap besaran kredit dengan nilai $p$-value 0,000 . Debitur yang mengambil tipe angsuran pertama dibayar dimuka (ADDM) bersamaan dengan pembayaran uang muka akan mempunyai besaran kredit lebih rendah 4,851 juta rupiah dibandingkan debitur yang mengambil tipe angsuran pertama dibayar dibelakang (ADDB) saat jatuh tempo pertama sesuai nilai koefisiennya. Hal ini dapat dijelaskan karena customer yang mengambil tipe ADDM, nilai besaran kreditnya akan berkurang sebanyak satu angsuran pada saat pembayaran uang muka sehingga lebih rendah dibandingkan debitur yang mengambil tipe ADDB.

Tipe kendaraan yang dipilih debitur akan menentukan besaran kredit (total pinjaman) yang disalurkan oleh perusahaan. Dengan nilai p-value 0,000 , ketiga dummy variabel tipe kendaraaan berpengaruh nyata terhadap besaran kredit. Debitur yang mengambil Tipe kendaraan LCGC (Low Cost Green Car), mempunyai besaran kredit lebih rendah 6,517 juta rupiah dibandingkan dengan debitur yang mengambil tipe kendaraan lainnya. Hal ini sesuai dengan koefisien persamaan regresi dan juga harga kendaraan LCGC memang cenderung lebih murah dibandingkan dengan harga kendaraan lainnya. Sebagai tipe kendaraan entry level, harga LCGC disesuaikan untuk menjangkau debitur muda yang baru punya kendaraan pertama kali. Hasil ini sesuai dengan penelitian Prieto dan Caemmerer (2013), yang menyatakan bahwa pembiayaan mobil, dalam hal ini secara kredit, berdampak positif pada pembelian mobil baru. Efek ini lebih kuat untuk segmen yang lebih rendah daripada segmen mobil yang lebih tinggi.

Tipe kendaraan minibus memiliki besaran kredit lebih tinggi 1,364 juta rupiah dibandingkan dengan tipe kendaraan lainnya sesuai koefisien regresinya. Hal ini karena harga tipe minibus kisaran harganya berada di atas tipe kendaraan yang lain, sehingga nilai besaran kreditnya juga lebih tinggi. Sedangkan tipe kendaraan Truck \& Pick Up mempunyai nilai besaran kredit lebih rendah 9,369 juta rupiah dibandingkan dengan tipe kendaraan lainnya. Kendaraan yang dijadikan sebagai agunan berpengaruh terhadap besaran kredit. Hasil ini sesuai dengan 
penelitian Itoo et al. (2013), Adrianda (2011), dan Suardi (2016), yang menyatakan bahwa jenis jaminan atau bentuk agunan berkorelasi positif dengan kegagalan bayar.

Tingkat pendidikan debitur juga berpengaruh nyata terhadap besaran kredit yang disalurkan perusahaan. Debitur dengan pendidikan sarjana cenderung diberikan besaran kredit lebih besar 0,525 juta rupiah dibandingkan debitur dengan pendidikan selain sarjana. Hasil penelitian ini sesuai dengan penelitian Chen dan Chivakul (2008), yang menyatakan pendidikan sarjana berpengaruh positif terhadap pemberian pinjaman. Pendapat ini diperkuat oleh penelitian Sekyi (2017) yang menyatakan pendidikan merupakan variabel yang signifikan terhadap jumlah pinjaman atau besaran kredit.

Pengaruh variabel gender terhadap besaran kredit didapatkan dengan koefisien negatif, dimana untuk gender laki-laki cenderung diberikan besaran kredit lebih rendah 0,641 juta rupiah dibandingkan dengan gender lainnya. Sekyi (2017) menyatakan gender juga merupakan variabel yang signifikan terhadap jumlah pinjaman atau besaran kredit. Itoo et al. (2013) dalam penelitiannya menyatakan bahwa jenis kelamin berkorelasi positif dengan jumlah pinjaman yang mengalami kegagalan bayar. Menurut Yohana (2011) faktor resiko yang signifikan mempengaruhi kredit macet untuk skala usaha mikro kecil dan menengah salah satunya adalah faktor jenis kelamin. Jenis kelamin laki-laki memiliki performance pembayaran kredit lebih baik menurut Nanayakkara dan Stewart (2015).

Paket kredit dibuat untuk menarik customer lebih banyak, karena menawarkan beberapa kondisi yang disukai oleh segmen tertentu sebagai targetnya. Paket kredit berpengaruh nyata terhadap besaran kredit (total pinjaman) dengan angka $p$-value 0,000 . Debitur yang mengambil pembiayaan tipe paket mempunyai besaran kredit lebih besar 5,997 juta rupiah dibandingkan dengan debitur yang mengambil tipe pembiayaan non paket. Hal ini terjadi jika debitur mengambil paket uang muka murah, maka besaran kreditnya akan lebih besar. Demikian juga jika debitur mengambil paket cicilan murah, maka tenornya akan lebih panjang dan bunga kredit yang dikenakan lebih besar, sehingga besaran kredit atau total pinjamannya akan lebih besar.

Variabel dummy tenor menggunakan tenor 12 (satu tahun) sebagai pembanding. Semua variabel dummy tenor berpengaruh nyata terhadap Besaran kredit yang diberikan kepada debitur dengan nilai $\mathrm{p}$-value 0,000 . Debitur dengan tenor-24 atau dua tahun mempunyai nilai besaran kredit 8,477 juta rupiah lebih besar dibandingkan debitur dengan tenor-12. Debitur dengan tenor36 atau tiga tahun mempunyai nilai besaran kredit 23,342 juta rupiah lebih besar dibandingkan debitur dengan tenor-12. Perbedaan ini semakin besar pada debitur dengan tenor-48 atau empat tahun. Nilai besaran kredit debitur tenor-48 lebih besar 37,259 juta rupiah dibandingkan debitur dengan Tenor-12. Perbedaan terbesar terdapat pada debitur dengan tenor-60 atau lima tahun, dimana nilai besaran kreditnya lebih besar 58,357. Hal ini sesuai dengan kondisi aktual, dimana untuk debitur dengan tenor makin panjang, akan dikenakan bunga kredit yang makin mahal.

Tenor atau jangka waktu pembiayaan menurut Yusuf W. et al. (2009), Musthikaningtyas (2011), Yudha (2011), Lusian (2015), dan Suardi (2016), berpengaruh terhadap NPL dan status kredit. Keputusan dalam menetapkan periode kredit (tenor) yang diberikan merupakan hal yang sulit bagi penjual (kreditur). Periode kredit yang lebih lama dapat melibatkan risiko gagal bayar (Shah, et al. 2015). Menurut Yohana (2011) mempersingkat jangka waktu kredit dapat mengurangi resiko gagal bayar seseorang.

Berdasarkan uraian di atas, tanda (+/-) koefisien pada persamaan regresi yang didapatkan dalam menganalisis faktor-faktor yang memengaruhi bsaran kredit (total pinjaman) di PT TAF sudah sesuai dengan kondisi penyalurannya di perusahaan. Hal ini diperkuat dengan model summary pada Tabel 3 dibawah dimana R-Square juga menunjukkan persamaan yang terbentuk memiliki nilai koefisien determinasi sebesar 97,8 persen. Pada persamaan regresi linear berganda ini, interpretasi variabel prediktor sudah sesuai untuk digunakan membangun model. 
Tabel 3. Model Summary regresi linear berganda besaran kredit (total pinjaman)

\begin{tabular}{rrrrr}
\hline Model & $\mathrm{R}$ & $\mathrm{R}$ Square & Adjusted $\mathrm{R}$ Square & Std. Error of the Estimate \\
\hline 1 &, $989^{\mathrm{a}}$ &, 978 &, 978 & 13,248 \\
\hline
\end{tabular}

Analisis Faktor-faktor yang Memengaruhi Non Performing Financing di PT TAF

Analisis faktor-faktor yang memengaruhi Non Performing Financing di PT TAF dilakukan dengan menggunakan Binary Logistic Regression. Hal ini dilakukan karena kategori variabel dependen (NPF) yang bersifat biner. Pada analisis kedua ini, besaran kredit (total pinjaman) yang pada analisis sebelumnya adalah variabel dependen, pada persamaan ini hasil analisis yang berupa dugaan besaran kredit $\left(\hat{Y}_{1}\right)$ dijadikan variabel independen. Variabel lain yang digunakan adalah Loan to value (LTV), tingkat inflasi saat kredit disalurkan, area debitur, dan segmen bisnis debitur. Hasil analisis regresi logistik biner ditampilkan pada Tabel 4 berikut.

Tabel 4. Hasil regresi logistik biner Non Performing Financing (NPF)

\begin{tabular}{lllll}
\hline & $\mathrm{B}$ & $\mathrm{p}$-value & $\operatorname{Exp}(\mathrm{B})$ & Goodness of Fit $^{\mathrm{a}}$ \\
\hline Constant & $-7,287$ & 0,000 & 0,001 & 0,000 \\
$\hat{Y}_{1}$ (Fits) & 0,004 & 0,000 & 1,004 & \\
LTV & 0,068 & 0,000 & 1,071 & \\
Inflasi & 0,090 & 0,000 & 1,094 & \\
Area Jawa & 0,169 & 0,001 & 1,184 & \\
Area Sumatera & 0,514 & 0,000 & 1,671 & \\
Segmen Jasa \& Perdagangan & $-0,031$ & 0,305 & 0,970 & \\
\hline
\end{tabular}

${ }^{a}$ Uji Hosmer-Lemeshow , $\hat{Y}_{1}$ (Fits) $=$ nilai dugaan besaran kredit

Berdasarkan Tabel 4, variabel $\hat{Y}_{1}$ (Fits) atau nilai dugaan besaran kredit berpengaruh nyata terhadap Non Performing Financing dengan nilai p-value 0,000. Nilai odds rasio $(\operatorname{Exp}(\mathrm{B}))$ untuk $\hat{Y}_{1}$ sebesar 1,004. Nilai odds ratio tersebut bisa diartikan bahwa setiap kenaikan dugaan besaran kredit $\left(\hat{Y}_{1}\right)$ sebesar satu juta rupiah, akan mengakibatkan kecenderungan menjadi NPF sebesar 1.004 kali. Menurut Agustinus (2008), semakin meningkatnya besaran kredit, maka NPL akan semakin meningkat. Besaran kredit atau plafon pinjaman atau maksimum kredit berpeluang signifikan atas terjadinya NPL menurut Rachmat (2009), Musthikaningtyas (2011), Itoo et al. (2013), Setiyaningsih (2015), Rasyidi et al. (2015), dan Suardi (2016). Hasil berbeda dinyatakan oleh Sitorus (2015) bahwa eksposur pinjaman tidak memberikan pengaruh signifikan terhadap kegagalan bayar.

Nilai dugaan besaran kredit $\left(\hat{Y}_{1}\right)$ dihasilkan dari regresi linear faktor-faktor besaran kredit pada analisis sebelumnya, maka semua faktor yang berpengaruh nyata terhadap besaran kredit akan cenderung berpengaruh nyata juga terhadap NPF. Faktor-faktor tersebut adalah harga kendaraan, umur debitur, bunga kredit, jumlah angsuran, penghasilan, uang muka, tipe angsuran pertama, tipe kendaraan, tipe pekerjaan, gender, pendidikan debitur, paket pembiayaan dan tenor. Perubahan nilai dari faktor-faktor tersebut akan memberikan pengaruh terhadap kemungkinan terjadinya NPF sesuai tanda dalam persamaan regresi linear berganda sebelumnya. Hal ini sesuai dengan hasil penelitian Musthikaningtyas (2011) yang menyatakan bahwa peubah penjelas yang signifikan berpengaruh terhadap ketidaklancaran (NPL) maupun kelancaran pembayaran adalah penghasilan, angsuran, maksimum kredit, umur, tenor dan suku bunga. Hasil penelitian ini juga sesuai dengan penelitian Yusuf et al. (2009), Messai dan Jouini (2013), Abadi (2014), Rasyidi et al. (2015), Suardi (2016), dan Murthy et al. (2017).

Variabel LTV berpengaruh nyata terhadap NPF dengan nilai p-value 0,000. Nilai odds rasio LTV sebesar 1,074, dapat diartikan setiap kenaikan LTV satu persen (\%) maka NPF akan cenderung naik sebesar 1,074 kali. Semakin besar LTV, pokok hutang dan bunga kredit yang ditanggung debitur akan semakin besar. Pinjaman yang semakin besar akan meningkatkan kemungkinan terjadinya kegagalan bayar dalam perjalanan kreditnya. Hal ini di perkuat dengan diagram Non Performing Financing berdasarkan nilai Loan to Value yang ditampilkan dalam Gambar 8 . 


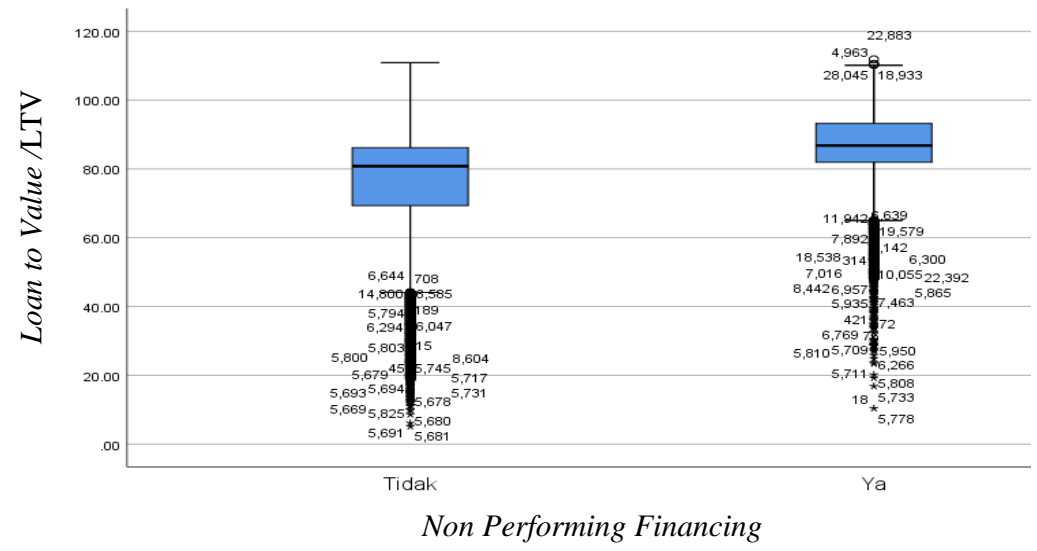

Gambar 8. Diagram kotak-garis Non Performing Financing (NPF) berdasarkan Loan to value (LTV)

Berdasarkan Gambar 8 tersebut, debitur dengan kategori tidak NPF sebagian besar memiliki LTV kurang dari 80 persen. Sedangkan debitur dengan kategori NPF sebagian besar memiliki LTV lebih dari 80 persen. Sehingga dapat dikatakan LTV debitur yang NPF secara umum lebih tinggi dibanding yang tidak NPF. Peningkatan rasio pinjaman terhadap nilai agunan (LTV) meningkatkan kemungkinan gagal bayar menurut Agarwal et al. (2008) yang didukung hasil penelitian Adrianda (2011), Itoo et al. (2013), dan Lusian (2015). Pengaruh LTV terhadap kegagalan bayar juga diteliti oleh Ghulam et al. (2018) yang menyatakan bahwa debitur dengan penghasilan rendah yang mendapatkan pinjaman dengan LTV tinggi dan membeli mobil mahal dalam jangka waktu yang lebih pendek, memiliki kemungkinan gagal bayar lebih tinggi.

Mengingat dampak besarnya LTV terhadap kenaikan NPF yang dapat meningkatkan kerugian perusahaan pembiayaan, Otoritas Jasa Keuangan sebagai regulator menerbitkan peraturan yang mengatur tentang besaran uang muka pembiayaan. Kenaikan uang muka diharapkan akan menurunkan LTV pada perusahaan pembiayaan dan mencegah dampak peningkatan NPF serta kerugian. Peraturan tersebut dituangkan dalam POJK Nomor 35/POJK.05/2018 tanggal 27 Desember 2018 tentang Penyelenggaraan Usaha Perusahaan Pembiayaan. Aturan uang muka pembiayaan kendaraan secara ringkas ditampilkan pada Tabel 5 berikut.

Tabel 5. Peraturan uang muka minimal pembiayaan kendaraan berdasarkan POJK No 35/POJK.05/2018

\begin{tabular}{|c|c|c|c|c|}
\hline \multirow{2}{*}{$\begin{array}{c}\text { Tingkat } \\
\text { Kesehatan } \\
\text { Keuangan } \\
\text { Perusahaan }\end{array}$} & \multirow[b]{2}{*}{$\begin{array}{l}\text { Ratio NPF } \\
\text { Perusahaan }\end{array}$} & \multicolumn{3}{|c|}{ Minimal Uang Muka Kendaraan } \\
\hline & & Roda $2 \& 3$ & $\begin{array}{c}\text { Roda } 4 \text { atau lebih } \\
\text { Pembiayaan Investasi }\end{array}$ & $\begin{array}{l}\text { Roda } 4 \text { atau lebih } \\
\text { Pembiayaan } \\
\text { Multiguna }\end{array}$ \\
\hline Sehat & $0-1 \%$ & $0 \%$ & $0 \%$ & $0 \%$ \\
\hline Sehat & $>1 \%-\leq 3 \%$ & $10 \%$ & $10 \%$ & $10 \%$ \\
\hline Sehat & $>3 \%-\leq 5 \%$ & $15 \%$ & $15 \%$ & $15 \%$ \\
\hline Tidak Sehat & $\leq 5 \%$ & $15 \%$ & $15 \%$ & $20 \%$ \\
\hline Tidak Sehat & $>5 \%$ & $20 \%$ & $20 \%$ & $25 \%$ \\
\hline
\end{tabular}

Berdasarkan Tabel 4, variabel tingkat inflasi yang berpengaruh nyata terhadap NPF dengan nilai $p$-value 0,000. Setiap ada kenaikan inflasi sebesar satu persen (\%) pada saat penyaluran kredit ke debitur, maka NPF cenderung akan naik sebanyak 1,094 kali sesuai odds rasio sebesar 1,094. Kecenderungan NPF naik pada kenaikan tingkat inflasi bisa disebabkan pada saat inflasi naik, maka bunga kredit yang dikenakan ke debitur cenderung naik. Sehingga beban angsuran yang ditanggung oleh debitur akan lebih besar dibandingkan debitur yang mengambil kredit saat inflasi rendah, dengan asumsi skema kredit lainnya tetap. Namun hasil ini belum bisa menjelaskan apakah kenaikan inflasi pada saat berjalannya kredit berpengaruh terhadap NPF. 
Variabel inflasi menurut Firmansyah (2014), Nurismalatri (2017), Barus dan Erick (2016), dan Mazreku et al. (2018) berpengaruh negatif terhadap pembiayaan bermasalah. Pada saat masyarakat menurun daya belinya akibat kenaikan inflasi, ternyata tidak mengurangi kewajibannya dalam melunasi hutang pembiayaannya. Sedangkan menurut Vanni (2017), inflasi berpengaruh positif tetapi tidak signifikan terhadap NPF. Menurut Was'an (2016), perubahan inflasi direspon negatif oleh hampir seluruh NPF sektor ekonomi kecuali NPF sektor konstruksi dan sektor pengangkutan, pergudangan dan komunikasi. Masih berdasarkan Tabel 4, dummy variabel area debitur tinggal berpengaruh nyata terhadap NPF. Untuk debitur yang tinggal di area Jawa mempunyai nilai p-value 0,001 , dengan odds rasio sebesar 1,184 . Odds rasio tersebut menunjukkan kecenderungan debitur yang tinggal di area Jawa mempunyai peluang untuk menjadi NPF 1,184 kali dibandingkan dengan debitur di area lainnya. Sedangkan debitur yang tinggal di area Sumatera mempunyai kecenderungan untuk menjadi NPF sebesar 1,671 kali dibandingkan dengan area lainnya sesuai nilai odds rasionya.

Tingginya kecenderungan NPF di area Sumatera bisa disebabkan sebagian debitur mempunyai bisnis di komoditas kelapa sawit, karet dan batubara yang harganya fluktuatif. Sehingga setiap ada penurunan harga, mempengaruhi kemampuan bayar tepat waktu dari debitur. Hasil penelitian ini sesuai dengan penelitian terdahulu. Variabel wilayah menurut penelitian Suardi (2016) mempunyai peluang signifikan terjadinya NPL. Hal ini diperkuat hasil penelitian Agustinus (2008) yang menyatakan lokasi berpengaruh positif terhadap NPL. Segmen bisnis debitur tidak berpengaruh nyata terhadap NPF dengan nilai $p$-value 0,305 . Hasil ini juga menunjukkan tidak adanya perbedaan kecenderungan debitur menjadi NPF antara segmen bisnis Jasa \& perdagangan dengan segmen bisnis lainnya. Semua segmen bisnis mempunyai mempunyai kecenderungan menjadi NPF yang sama. Hasil ini berbeda dengan penelitian Suardi (2016) yang menyatakan sektor perdagangan lebih berpengaruh terhadap kelancaran pembayaran daripada non perdagangan.

Hasil persamaan regresi logistik yang dalam penelitian ini diharapkan mampu membuat prediksi kemungkinan debitur menjadi NPF. Sehingga perusahaan mempunyai waktu untuk mempersiapkan tindakan antisipasinya. Untuk menguji kesesuaian prediksi kemungkinan debitur menjadi NPF atau tidak maka dibuat tabulasi silang seperti ditampilkan dalam Tabel 6. Berdasarkan Tabel 6, diketahui tingkat akurasi persamaan ini untuk memprediksi debitur NPF, dan aktualnya NPF adalah 74,5 persen. Sementara keakurasian hasil prediksi debitur tidak NPF dan aktualnya tidak NPF adalah 62,7 persen. Secara keseluruhan persamaan ini mempunyai ketepatan prediksi baik debitur NPF atau tidak NPF adalah 68,5 persen. Sehingga persamaan ini dapat digunakan untuk memprediksi apakah seorang debitur akan NPF atau tidak.

Tabel 6. Tabulasi silang prediksi Non performing Financing (NPF)

\begin{tabular}{lllcc}
\hline \multirow{2}{*}{ Aktual } & \multicolumn{3}{c}{ Prediksi } \\
\cline { 3 - 4 } & & \multicolumn{2}{c}{ NPF } & Persentase (\%) \\
\cline { 3 - 4 } & Tidak & Ya & 62,7 \\
\hline NPF & Tidak & 7,219 & 4,288 & 74,5 \\
\hline Ya & 2,848 & 8,306 & 68,5 \\
\hline
\end{tabular}

\section{Perumusan strategi PT TAF dalam mengendalikan NPF di masa yang akan datang}

Berdasarkan hasil penelitian dirumuskan strategi untuk mengendalikan NPF dan mengurangi kerugian kredit. Beberapa strategi yang dapat digunakan adalah:

1. PT TAF harus memperhatikan dan mempertimbangkan faktor-faktor yang memengaruhi besaran kredit dalam memberikan persetujuan kredit ke calon debitur. Faktor-faktor yang perlu diperhatikan adalah harga kendaraan, umur, bunga kredit, jumlah angsuran, penghasilan, uang muka, tipe angsuran pertama, tipe kendaraan, pendidikan, gender, paket kredit dan tenor kredit. Selain itu juga pemberian kredit di area tertentu seperti Sumatera dan

2. Hasil penelitian menunjukkan bahwa LTV berpengaruh nyata terhadap kecenderungan debitur menjadi NPF atau tidak NPF. Setiap kenaikan LTV satu persen (\%) maka NPF akan 
cenderung naik sebesar 1,074 kali. Selain itu debitur dengan kategori tidak NPF sebagian besar memiliki LTV kurang dari 80 persen. Sedangkan debitur dengan kategori NPF sebagian besar memiliki LTV lebih dari 80 persen. Berdasarkan hasil tersebut maka diharapkan PT TAF memperbanyak portofolio debitur dengan LTV kurang atau sama dengan 80 persen, untuk memperkecil resiko kerugian kredit. Paket dengan uang muka murah yang menyebabkan LTV tinggi harus diperuntukkan debitur yang memiliki kemampuan bayar yang baik.

3. Besaran kredit atau total pinjaman berpengaruh nyata terhadap NPF dengan kecenderungan setiap kenaikan dugaan besaran kredit ( $\hat{Y}_{1}$ ) sebesar satu juta rupiah, akan mengakibatkan kecenderungan menjadi NPF sebesar 1,004 kali. Faktor-faktor yang berpengaruh nyata terhadap besaran kredit akan cenderung berpengaruh nyata juga terhadap NPF. Faktor yang berpengaruh besar terhadap besaran kredit antara lain harga kendaraan, bunga kredit, dan tenor kredit. Sedangkan uang muka berpengaruh negatif terhadap besaran kredit. Berdasarkan hasil tersebut, maka PT TAF disarankan menghindari produk pembiayaan dengan uang muka rendah dan tenor panjang. Karena semakin rendah uang muka, semakin panjang tenor, besaran kredit akan meningkat, dan meningkatkan kecenderungan debitur menjadi NPF.

4. Area Jawa dan area Sumatera berpengaruh nyata terhadap NPF, dengan perbandingan terbesar di area Sumatera kecenderungan NPF sebesar 1,671 kali dibanding dengan area lainnya. Untuk mengantisipasi hal ini, coverage penagihan debitur di area Jawa dan terutama area Sumatera yang cukup luas harus mencukupi. Penguatan struktur organisasi AR Management/collection dan peningkatan kemampuan team collection menjadi salah satu kunci keberhasilan. Debitur yang mengalami keterlambatan harus diselesaikan sebelum mengalir ke kategori NPF. Mengingat bahwa debitur PT TAF yang tinggal di area Jawa dan Sumatera memiliki jumlah lebih besar dibandingkan dengan area lainnya, serta market pembiayaan mobil masih terkonsentrasi di Jawa dan Sumatera, maka penguatan team collection di area tersebut masih lebih menguntungkan dibandingkan membuka pasar baru di luar area Jawa dan Sumatera.

5. Sebagai tambahan strategi, sesuai dengan Peraturan Otoritas Jasa Keuangan Nomor 18 /POJK.03/2017. PT TAF dapat memanfaatkan informasi yang ada di Sistem Layanan Informasi Keuangan (SLIK) dari OJK untuk memperoleh informasi tambahan mengenai riwayat kredit calon debitur. Informasi yang bisa didapatkan dari SLIK berupa data debitur, fasilitas penyediaan dana, agunan, penjamin, pengurus dan pemilik serta keuangan debitur. Berdasarkan tambahan informasi tersebut diharapkan PT TAF dapat memutuskan kredit lebih baik.

\section{KESIMPULAN}

Pemahaman faktor-faktor yang memengaruhi besaran kredit dan NPF sangat penting dalam bisnis perusahaan pembiayaan. Terutama dalam penyusunan strategi untuk menghindari kerugian akibat peningkatan NPF. Penelitian ini dilakukan untuk menjawab hal tersebut. Simpulan yang dihasilkan dalam penelitian adalah ini adalah sebagai berikut:

1. Faktor-faktor yang berpengaruh nyata terhadap besaran kredit adalah harga kendaraan, umur, bunga kredit, jumlah angsuran, penghasilan, uang muka, tipe angsuran pertama, tipe kendaraan, pendidikan, gender, paket kredit dan tenor kredit. Faktor yang berpengaruh positif adalah harga kendaraan, umur, bunga kredit dan jumlah angsuran. Sedangkan uang muka dan penghasilan berpengaruh negatif terhadap besaran kredit.

2. Faktor-faktor yang berpengaruh nyata terhadap NPF adalah besaran kredit, LTV, inflasi, area Jawa dan area Sumatera. Faktor besaran kredit, LTV, dan inflasi berpengaruh positif terhadap NPF. 


\section{DAFTAR PUSTAKA}

Abadi, S. (2014). Analisis sensitivitas NPL sektoral perbankan Indonesia terhadap perubahan faktor ekonomi [tesis]. Bogor: IPB.

Abhyankar, A. (2012). A study on growth of automobile industry and determinants of demand and preference pattern of automobile ownership. Anvesha, 5(2), 25-31.

Adrianda, A. (2011). Analisis faktor-faktor yang mempengaruhi kolektibilitas kredit debitur pada Cabang Area II Jakarta- Bank XYZ, Tbk [tesis]. Bogor (ID): IPB.

Agustinus, J. (2008). Variabel-variabel yang memengaruhi Non Performing Loans pada bank BUMD, BUMN dan BUSN di kota Jayapura. Jurnal Keuangan dan Perbankan, 12(3), 504 516.

Agarwal, S., Ambrose, B. W., \& Chomsisengphet, S. (2008). Determinants of automobile loan default and prepayment. Economic Perspectives, 32(3), 17-28.

Ali, M. (2006). Manajemen Risiko. Jakarta: PT. RajaGrafindo Persada.

Barus, A. C., \& Erick. (2016). Analisis faktor-faktor yang mempengaruhi Non Performing Loan pada bank umum di Indonesia. Jurnal Wira Ekonomi Mikroskil, 6(2), 113-122.

Budiana, D. (2017). Pengaruh faktor-faktor makro dan mikro ekonomi terhadap NPL UMK Bank XYZ [tesis]. Bogor: IPB.

Chen, K. C., \& Chivakul, M. (2008). What drives household borrowing and credit constraints? Evidence from Bosnia and Herzegovina. IMF Working Paper, 8(202), 1-34.

Danny, B. S. (2008). Default, credit scoring, and Loan-to-Value: A theoretical analysis of competitive and non-competitive mortgage markets. The Journal of Real Estate Research, 30(2), 161-190.

Dewi, M. D. K, \& Suryanawa, I. K. (2015). Pengaruh tingkat suku bunga, profesi nasabah kredit, efektifitas Badan Pengawas pada Non Performing Loan. E-Jurnal Akuntansi Universitas Udayana, 13(3), 779-795.

Firmansyah, I. (2014). Determinant of Non Performing Loan: The case of Islamic Bank in Indonesia. Buletin Ekonomi Moneter dan Perbankan, 17(2), 241-258.

Garson, G. D. (2014). Logistic Regression: Binary and Multinomial. Ed 2014. North Carolina: Statistical Publishing Associates.

Ghulam, Y., Dhruva, K., Naseem, S., \& Hill, S. (2018). The interaction of borrower and loan characteristics in predicting risks of subprime automobile loans. Risks, 6(3), 1-21.

Hosmer, D.W., \& Lemeshow, S. (2000). Applied Logistic Regression. New York: John Wiley \& Sons, Inc.

Itoo, R. A., Mutharasu, S. A., \& Filipe, J. A. (2013). Effect of loan value and collateral on value of mortgage default . International Journal of Latest Trends in Finance \& Economic Sciences, $3(4), 635-651$.

Lusian, S. (2015). Analisis faktor-faktor penyebab pembiayaan bermasalah di Bank Pembiayaan Rakyat Syariah XY Z periode 2009-2013 [tesis]. Bogor: IPB.

Mazreku, I., Morina, F., Misiri, V., Spiteri, J. V., \& Grima, S. (2018). Determinants of the level of Non-Performing Loans in commercial banks of transition countries. European Research Studies Journal, 21(3), 3 - 13.

Messai, A. S., \& Jouini, F. (2013). Micro and macro determinants of Non-performing Loans. International Journal of Economics and Financial Issues, 3(4), 852-860.

Murthy, U., Kamil, M. N., Mariadas, P. A., \& Devi, D. (2017). Factors influencing NonPerforming Loans in commercial banks: The case of banks in Selangor. International Journal of Business and Management, 12(2), 246-254.

Musthikaningtyas, N. R. (2011). Analisis faktor-faktor yang mempengaruhi Non Performing Loan (NPL) Kredit Pemilikan Rumah (KPR) [tesis]. Bogor: IPB.

Nanayakkara, G., \& Stewart, J. (2015). Gender and other repayment determinants of microfinancing in Indonesia and Sri Lanka. International Journal of Social Economics. 42(4), 322-339. 
Nurismalatri. (2017). Analisis pengaruh makro ekonomi terhadap kredit bermasalah perbankan Indonesia. Jurnal Sekuritas, 1(2), 103-116.

[OJK] Otoritas Jasa Keuangan. (2005). Peraturan Otoritas Jasa Keuangan Nomor 29/POJK.05/2014 tanggal 19 November 2014 tentang Perizinan Usaha dan Kelembagaan Perusahaan Pembiayaan. Jakarta: Otoritas Jasa Keuangan.

(2017). Peraturan Otoritas Jasa Keuangan Nomor 18/POJK.03/2017 tanggal 26 April 2017 tentang Pelaporan dan Permintaan Informasi Debitur Melalui Sistem layanan Informasi Keuangan. Jakarta: Otoritas Jasa Keuangan.

(2018). Peraturan Otoritas Jasa Keuangan Nomor 35/POJK.05/2018 tanggal 27 Desember 2018 tentang Penyelenggaraan Usaha Perusahaan Pembiayaan. Jakarta: Otoritas Jasa Keuangan.

Prieto, M., \& Caemmerer, B. (2013). An exploration of factors influencing car purchasing decisions. International Journal of Retail \& Distribution Management, 41(10), 738-764.

PT. Toyota Astra Financial Services. (2015). Laporan Tahunan Tahun 2013. Jakarta: PT Toyota Astra Financial Services.

Astra Financial Services.

(2015). Laporan Tahunan Tahun 2014. Jakarta: PT Toyota

(2015). Laporan Tahunan Tahun 2015. Jakarta: PT Toyota

Astra Financial Services.

(2016). Laporan Tahunan PT Toyota Astra Financial

Services Tahun 2016. Jakarta: PT Toyota Astra Financial Services.

(2017). Laporan Tahunan PT Toyota Astra Financial

Services Tahun 2017. Jakarta: PT Toyota Astra Financial Services.

Rachmat MI. (2009). Pengaruh karakteristik debitur terhadap kelancaran pembayaran kredit Bank XYZ [tesis]. Bogor: IPB.

Rasyidi, A., Firdaus, M., \& Sasongko, H. (2015). The factors that influence the loan repayments of credit union members and performance analysis on credit union. International Journal of Administration Science \& Organization, 22(1), 1-15.

Shah, N. H., Shah, D. B., \& Patel, D. G. (2015). Optimal credit period and purchase quantity for credit dependent trended demand. OPSEARCH, 52(1), 101-107.

Sekyi, S. (2017). Rural households' credit access and loan amount in Wa Municipality, Ghana. International Journal of Economics and Financial Issues, 7(1), 506-514.

Setiyaningsih, Juanda, B., \& Fariyanti, A. (2015). Faktor-faktor yang memengaruhi ratio Non Performing Loan (NPL). Jurnal Aplikasi Bisnis dan Manajemen, 1(2), 23-33.

Sitorus, T. (2015). The study of risk-weighted assets on the effects of loan exposure valuation towards credit default. Copernican Journal of Finance \& Accounting, 4(2), 159-176.

Suardi, I. (2016). Analisis faktor-faktor yang mempengaruhi Non Performing Loan (NPL) kredit mikro dan dampaknya terhadap penyaluran kredit pada sektor mikro di PT Bank XYZ kantor Wilayah X [tesis]. Bogor: IPB.

Vanni, K. M., \& Rokhman, W. (2017). Analisis faktor-faktor yang mempengaruhi Non Performing Financing pada perbankan syariah di Indonesia tahun 2011-2016. Equilibrium, 5(2), 307-319.

Yohana, H. (2011). Analisis resiko kredit UMKM dengan analisis daya tahan [tesis]. Bogor: IPB.

Yudha, A. P. (2011). Analisa risiko kredit macet KPR bersubsidi [tesis]. Bogor: IPB.

Yusuf, W., Pratikto, F. R., \& Vivianne, A. S. (2009). Evaluasi pemohon kredit mobil di PT "X" dengan menggunakan teknik data mining decision tree. Simposium Nasional RAPI VIII, 4249.

Was'an, G. H. (2016). Kaitan kondisi makroekonomi dengan Non Performing Financing (NPF) berdasarkan sector ekonomi pada perbankan syariah di Indonesia [tesis]. Bogor: IPB

Indonesian Automobile Industry Data-Gaikindo [internet]. [Diunduh pada: 2018 Mei 23]. Tersedia pada: https://www.gaikindo.or.id/indonesian-automobile-industry-data/. 
Inflation report (Consumer Price Index) based on year on year measurement data-Bank Indonesia [internet]. [Diunduh pada: 2018 Juni 02]. Tersedia pada: https://www.bi.go.id/en/moneter/inflasi/data/Default.aspx.

Statistik Lembaga Pembiayaan [internet]. [Diunduh pada: 2018 Maret 19]. Tersedia pada: https://ojk.go.id/id/kanal/iknb/data-dan-statistik/lembaga-pembiayaan/Default.aspx. 